\title{
Bacteriological Quality of Drinking Water Sources and Reservoirs Supplying Dharan Municipality of Nepal
}

\author{
Narayan Dutt Pant ${ }^{1 *}$, Nimesh Poudyal ${ }^{2}$, Shyamal Kumar Bhattacharya ${ }^{2}$
}

\begin{abstract}
Affiliations:
Hospital, Dhapasi, Kathmandu, Nepal Health Sciences, Dharan, Nepal

Correspondence to:

Narayan Dutt Pant

Medical Microbiologist

Department of Microbiology

Grande International Hospital

Dhapasi, Kathmandu, Nepal

Email:ndpant1987@gmail.com
\end{abstract}

'Department of Microbiology, Grande International

2Department of Microbiology, B.P. Koirala Institute of

How to cite this article:

Pant N D, Poudyal N, Bhattacharya S. Bacteriological Quality of Drinking Water Sources and Reservoirs Supplying Dharan Municipality of Nepal. Ann. Clin. Chem. Lab. Med. 2016:2(1);19-23

DOI: http://dx.doi.org/10.3126/acclm.v2i1.14271

(C) 2016 Nepalese Association for Clinical Chemistry

\section{(). (1) (2)}

This work is licensed under a Creative Commons Attribution-ShareAlike 4.0 International License.

\section{Abstract}

\section{BACKGROUND}

Nepal is one of the least developed countries and in most of the areas the water supplied directly from natural water sources (like streams, rivers etc.) is used for drinking purpose, without any prior treatment. So every year there are many water related outbreaks mainly in rainy season. Very little data is available about the bacteriological quality of the water from drinking water sources, in the country. This report presents a scenario of the bacteriological quality of the water from drinking water sources and reservoirs, supplying Dharan municipality of Nepal.

\section{METHODS}

Bacteriological analysis of the water samples was performed by membrane filter technique and spread plate technique. Total coliform count (TCC), fecal coliform count (FCC) and fecal streptococcal count (FSC) were performed by using membrane filter technique and total plate count (TPC) was performed by spread plate method.

\section{RESULTS}

Most of the sources and reservoir tanks were found to be heavily contaminated with heterotrophic bacteria, total coliforms, fecal coliforms and fecal streptococci. Contamination with more than one type of indicator organisms was common.

\section{CONCLUSIONS}

Most of the sources and reservoirs were found to be heavily contaminated with indicator organisms suggesting the alarming situation of water pollution in the area. Abrupt action is needed to be taken to improve the bacteriological quality of the water sources and reservoirs, supplying drinking water to Dharan municipality of Nepal.

KEYWORDS: Bacteriological quality, drinking water, fecal coliform, total coliform, total plate count, fecal streptococci. 


\section{Introduction}

Access to safe water is basic human need, however most of the human population mainly in developing countries do not have this privilege [1]. Worldwide, there have been countless numbers of disease outbreaks resulting from the consumption of unsafe drinking water [2]. According to world health organization $80 \%$ of all diseases in the world are either water or sanitation related [3]. United nation international children's emergency fund (UNICEF), reported that about 800 million people in Asia and Africa do not have access to safe drinking water. Consequently, this has caused many people to suffer from various water related illnesses like cholera, typhoid, dysentery etc. But proper management and treatment of water sources and supplies have greatly controlled the incidence of these diseases in developed countries [4]. In a report by world health organisation (WHO); it has been stated that about 30,000 people and children die everyday from water related diseases, more critically, in under developed countries. According to public health department, Nepal, about 3500 children are still dying in Nepal due to water borne diseases [5]. In Nepal bacteriological quality of the drinking water is a neglected issue. We are aware of only a few researches done in this field. Up to best of our knowledge no researches have been conducted to identify the bacteriological quality of water from sources supplying drinking water to most of the urban and rural areas of Nepal including Dharan municipality. It is a well known fact that the quality of the water from drinking water source determines the quality of the water reaching to the consumers in significant level and most of the natural water sources are highly contaminated [6]. In this study, we determined the bacteriological quality of the drinking water sources and reservoirs, supplying Dharan municipality of Nepal.

\section{Methods}

\section{WATER SAMPLES COLLECTION AND TRANSPORTATION:}

The samples were collected in sterile bottles using aseptic technique. For this the bottle was tied in a string and was dipped into the water body around $6 \mathrm{~cm}$ below the surface. For the sources (underground water) having outlet valve the water samples were collected aseptically from the valve. After the bottle was filled upto neck it was capped leaving some air space inside the bottle so that the strict aerobes if present will not get killed. Two water samples were collected from the sources where treatment plants were present; one before the treatment and another after treatment. In case of the sources having no treatment system and reservoirs, only one sample was taken. From both sources and reservoirs total ten samples were collected. The samples were carried to the water bacteriology laboratory of BPKIHS, Dharan maintaining cold chain within half an hour of collection and the samples were processed within 2 hours of collection.

ANALYSIS OF WATER SAMPLES

Bacteriological analysis of the water was performed by membrane filter technique and spread plate technique. Total coliform count (TCC), fecal coliform count (FCC), fecal streptococcal count (FSC) were performed by using membrane filter technique and total plate count (TPC) was performed by spread plate method. For TPC, total plate count agar was used. Similarly, for TCC m-endo agar les, for FCC eosin methylene blue agar and for FSC bile esculin agar were used. PH meter and thermometer were used to measure $\mathrm{pH}$ and temperature of the water respectively $[7,8,9] . \mathrm{pH}$ and temperature of the water were measured at the site of sample collection.

IDENTIFICATION OF THE BACTERIAL ISOLATES:

The bacteria isolated were identified by colony characteristics, gram reactions and conventional biochemical testing. The biochemical tests used were catalase test, oxidase test, citrate utilization test, urease test, sulphide indole motility test, triple sugar iron test, methyl-red voges proskauer test, lysine decarboxylase test, growth on bile esculin agar at $44.5^{\circ} \mathrm{C}$ etc.

QUALITY CONTROL:

Quality control procedures included collection of duplicate samples from each site and processing them parallely. For the quality control of the processing procedure a known sterile sample of water was processed along with the samples to be tested

\section{Results}

Most of the sources and reservoirs were found to be contaminated with indicator organisms. But water of all the sources and reservoirs had $\mathrm{pH}$ in acceptable range except in one sample. The temperature of the samples ranged from $14^{\circ} \mathrm{C}$ to $20^{\circ} \mathrm{C}$. Out of five sources four sources were found to be highly contaminated with heterotrophic bacteria $(\mathrm{p}<0.05)$. Similarly, three sources were found to be contaminated with total coliforms, fecal coliforms and fecal streptococci $(\mathrm{p}<0.05)$. Of 
the two sources having water treatment system in only one source (source 1), water treatment was relatively effective $(\mathrm{p}<0.05)$. In total of three reservoirs, two reservoirs were contaminated with heterotrophic bacteria $(p<0.05)$. Only one reservoir was found to be contaminated with fecal streptococci and which was statistically significant $(\mathrm{p}<0.05)$ [Table 1].

The bacteria isolated from different sources and reservoirs were Pseudomonas aeruginosa, Citrobacter freundii, Klebsiella pneumoniae, Enterobacter cloacae, Escherichia coli, Enterococcus fecalis, Proteus mirabilis, Acinetobacter baumannii and Bacillus cereus [Table 2].

\section{Discussion}

There are two types of sources to supply drinking water in Dharan municipality. One is underground water and another is surface water. The underground water is collected with the help of deep borings and is collected in a common reservoir (reservoir 3) before it is sent to a reservoir (reservoir 2) to mix it with the water from surface water sources. And in this reservoir (reservoir 2) the water is disinfected with bleaching powder before distributing. We sampled the water from two deep borings (source 4 and source 5) among a few borings as representative samples. There are three sources of surface water. Source 1 and source 2 are closed sources with sedimentation and flocculation unit but source 3 is an open source. The water from sources 1 and 2 are collected in reservoir 1 and some areas of Dharan are supplied from this reservoir without any prior treatment. The water from reservoir 1 and source 3 is sent to the reservoir 2.

Our findings are accordance with the findings of Aryal et al. in Arthunge VDC of Myagdi district, Nepal where 6/11 (54.55\%) of sources and 100\% of reservoirs were found to be heavily contaminated with indicator organisms [10]. In a similar study done by Pindi et al. in Mahabubnagar, Andhrapradesh, India all of the samples of main drinking water sources were found to be contaminated with indicator organisms up to unacceptable level [11]. Similar results were also obtained by Adam et al. in Sudan [12] and Tsega et al. in Ethiopia [1].

Table1. Characteristics of the water samples from sources and reservoirs.

\begin{tabular}{llcccccc}
\hline Sample & & Temp. $\left({ }^{\circ} \mathrm{C}\right)$ & $\mathrm{pH}$ & TPC/0.1ml & TCC/100ml & FCC/100ml & FSC/100ml \\
\hline \multirow{2}{*}{ Source 1 } & Bef.treat & 18 & 8.2 & 85 & 900 & 13 & 30 \\
& Aft.treat & 16 & 8.7 & 26 & 0 & 0 & 0 \\
Source 2 & Bef.treat & 16 & 8.1 & 70 & 1010 & 55 & 120 \\
Source 3 & Aft.treat & 14 & 8.1 & 125 & 990 & 53 & 113 \\
Source 4 & 19 & 7.7 & 175 & 1500 & 850 & 100 \\
Source 5 & 19 & 6.9 & 5 & 0 & 0 & 0 \\
Reservoir 1 & 19 & 7 & 0 & 0 & 0 & 0 \\
Reservoir 2 & 19 & 8 & 80 & 890 & 95 & 120 \\
Reservoir 3 & 17 & 7.3 & 0 & 0 & 0 & 0 \\
\hline
\end{tabular}

Note: Bef.treat: Before treatment, Aft.treat: After treatment, Temp: Temperature.

Table 2. Different bacteria isolated from the sources and reservoirs.

\begin{tabular}{|c|c|c|}
\hline Sample & & Bacteria isolated \\
\hline \multirow[t]{2}{*}{ Source 1} & Bef.treat & $\begin{array}{l}\text { Pseudomonas aeruginosa, Citrobacter freundii, Klebsiella pneumonia, } \\
\text { Escherichia coli, Proteus mirabilis, Enterococcus fecalis, Bacillus cereus. }\end{array}$ \\
\hline & Aft.treat & Pseudomonas aeruginosa \\
\hline \multirow{2}{*}{ Source 2} & Bef.treat & $\begin{array}{l}\text { Pseudomonas aeruginosa, Citrobacter freundii, Klebsiella pneumonia, } \\
\text { Escherichia coli, Enterococcus fecalis, Bacillus cereus. }\end{array}$ \\
\hline & Aft.treat & $\begin{array}{l}\text { Pseudomonas aeruginosa, Citrobacter freundii, Klebsiella pneumoniae, } \\
\text { Enterobacter cloacae, Escherichia coli, Enterococcus fecalis, Bacillus cereus. }\end{array}$ \\
\hline Source 3 & & $\begin{array}{l}\text { Pseudomonas aeruginosa, Citrobacter freundii, Escherichia coli, Proteus } \\
\text { mirabilis, Enterococcus fecalis, Bacillus cereus. }\end{array}$ \\
\hline $\begin{array}{l}\text { Source } 4 \\
\text { Source } 5\end{array}$ & & $\begin{array}{l}\text { Acinetobacter baumannii, Bacillus cereus. } \\
\text { No isolates }\end{array}$ \\
\hline Reservoir 1 & & $\begin{array}{l}\text { Pseudomonas aeruginosa, Citrobacter freundii, Klebsiella pneumoniae, } \\
\text { Escherichia coli, Enterococcus fecalis, Bacillus cereus. }\end{array}$ \\
\hline Reservoir 2 & & No isolates \\
\hline Reservoir 3 & & $\begin{array}{l}\text { Pseudomonas aeruginosa, Citrobacter freundii, Enterobacter cloacae, } \\
\text { Acinetobacter baumannii, Bacillus cereus. }\end{array}$ \\
\hline
\end{tabular}


Alotaibi in Saudi Arabia found the $80 \%$ of surface waters, and $100 \%$ of well waters to be heavily contaminated with indicator organisms [13]. In our study the underground water sources were found to be free from bacterial contamination but well water even being a type of underground water was found to be contaminated in the study by Alotaibi et al. [13]. This may be because of the well not being closed the contaminants can reach it easily. Similar to our study the bacteria isolated from water by Alotaibi et al were Escherichia coli, Klebsiella pneumoniae, Klebsiella oxytoca, Enterobacter cloacae, Enterobacter aerogens, Enterobacter agglomerans, Enterobacter gergoviae, Citrobacter freundii, Citrobacter diversus, Proteus vulgaris, and Proteus mirabilis [13]. Similar range of $\mathrm{pH}$ and temperature as in our study was also reported by Aryal et al. [10] and Pradhan [14].

The water treatment at source 1 was comparatively effective but that was not effective at source 2 . The ineffectiveness of the water treatment may be due to the inadequate amount of the disinfectant used leaving very low amount of residual disinfectant. Poor maintainance, constructional defects, human activities like open defecation, slaughtering, washing, bathing and cattle grazing nearby water sources must have contributed to the high concentration of the indicator organisms seen in the sources and reservoirs of the water. No disinfection was done in the reservoirs 1 and 3. Reservoir 1 may have been contaminated from the already contaminated sources of surface water. Even though the underground water which was found to be contamination free is collected in reservoir 3 , the water from the reservoir was found to be contaminated. The water in reservoir may be contaminated due to constructional defects like leakage points through which the contaminants (contaminated water or sewage) get infiltrated. The water from reservoir 2 was contamination free due to the effective disinfection. Presence of fecal coliforms indicates fecal contamination and the water may contain pathogenic organisms. The pathogens present in water may be of natural origin or may have been excreted by humans or warm blooded animals in their feces. As E. coli survives longer in water than most of the pathogens it is ideal indicator for recent or earlier fecal pollution [13].

Diarrheal diseases which are mostly related to the quality of the drinking water are the second most common diseases among the top ten diseases in Nepal [14]. So the microbial quality of the water sources should be monitored regularly to determine the primary source of contamination and hence to control it. Control measures in case of sudden outbreaks due to contamination of vital water sources should be planned. The water sources should be protected by fencing or by any other means to control the human and animal activities. Regular maintainance and supervision of water sources and reservoirs are recommended. The treatment units should be constructed in every sources and the proper disinfection of water should be carried out in sources as well as in all the reservoirs so that the possible contaminants at any points may be eliminated.

\section{Conclusion}

This study investigated the bacteriological quality of the sources and reservoirs in an urban area of Nepal so as to produce an overview of the current situation in the area. Most of the sources and reservoirs were found to be heavily contaminated with indicator organisms suggesting the alarming situation of water pollution in the area. If immediate measures are not taken to control it, the consequences may be very serious.

\section{Acknowledgement}

The authors would like to thank the staffs of Nepal drinking water corporation, Dharan for their kind support to provide the necessary information. We would like to appreciate the opportunity provided by B. P. Koirala institute of health Sciences to conduct this research.

\section{Conflict of Interest}

None declared.
1. Tsega N, Sahile S, Kibret M, Abera B. Bacteriological and physicochemical quality of drinking water sources in a rural community of Ethiopia. Afr Health Sci. 2013; 13(4):1156-61. http://dx.doi.org/10.4314/ahs.v13i4. 42

2. Mihdhdir AA. Evaluation of bacteriological and sanitary quality of drinking water stations and water

\section{REFERENCES}

tankers in Makkah Al-Mokarama. Pak J Biol Sci. 2009; 12(4):401-5. http://dx.doi.org/10.3923/pjbs.2009 .401 .405

3. Prasanna RB, Reddy MS. Bacteriological examination of drinking water with reference to coliforms in Jeedimetla, Hyderabad, India. Afr J Biotechnol. 2009; 8(20):5495-6.
4. Sadeghi GH, Mohammadian M, Nourani M, Peyda M, Eslami A. Microbiological quality assessment of rural drinking water supplies in Iran. J Agri Soc Sci. 2007; 3:31-3.

5. Bhandari MR, Gautam DN, Joshi S, Bhattarai UK. Quality assessment of drinking water commercially available in Kathmandu valley Nepal. Food Research Bulletin. 2009; 2:5-13. 
6. Stukel A, Greenberg ER, Dain BJ Reed FC, Jacobs NJ. A Longitudinal study of rainfall and coliform contamination in small community drinking water supplies. Environ sci Technol. 1990; 24:571-5.

http://dx.doi.org/10.1021/es00074a 610

7. World Health Organisation. Guidelines for drinking-water quality. 4th edition. Geneva: WHO. 2011.

8. Senior BW. Examination of water, milk, food and air. In: Collee JG, Fraser AG, Marmion BP, Simmons A, editors. Mackie and McCartney practical medical microbiology. 14th edition. India: Elsevier India Private Limited. 2007.
9. World Health Organisation. Guidelines for drinking water quality. Volume 3, 2nd edition. Surveillance and control of community supplies. Geneva: WHO. 1997.

10. Aryal J, Gautam B, Sapkota N. Drinking water quality assessment. J Nepal Health Res Counc. 2012; 10(22):192-6.

11. Pindi PK, Yadav PR, Kodaparthi A. Bacteriological and physicochemical quality of main drinking water sources. Pol J Environ Stud. 2013; 22(3):825-30.

12. Adam ME, Khalil OM, Ali EN. Bacteriological characterization of drinking water sources in villages of West Kordofan, Sudan.
International Research Journal of Microbiology. 2013; 4(5):125-30.

13. Alotaibi ELS. Bacteriological assessment of urban water sources in Khamis Mushait Governorate, southwestern Saudi Arabia. International Journal of Health Geographics. 2009; 8:16. http://dx.doi.org/10.1186/1476072X-8-16

14. Pradhan B. Rural communities perception on water quality and water borne disease: the case of Bungamati village development committee in Kathmandu valley, Nepal. Journal of Nepal Health Research Council. 2004; 2(1). 